\title{
Editorial
}

\section{A Europe crowded with branches?}

\author{
Fred C. de Hosson, Caron \& Stevens/Baker \& McKenzie, Amsterdam
}

It is obvious that, at the present time, one can only guess at the consequences of an internal market for the legal and tax structures of EEC-operating companies. There have been authors, however, who have ventured out onto this thin ice. One of them, and certainly not the least, has been Helmut Becker in an Intertax editorial of April last year. Becker anticipates a considerable increase in the number of permanent establishments within the EEC. ${ }^{1}$ In his view, one of the main causes of this future development is the Merger Directive, which requires that the majority of the facilitated transactions described in the Directive result in a permanent establishment in the Member States which must refrain from levying a direct tax on the transaction results. ${ }^{2}$

I find it somewhat hard to agree with the 'renaissance' of the permanent establishment, which Becker announced. The permanent establishment may be a business form to which learned tax professors like to devote extensive discussions, but in practice this form is carefully ignored. There are good reasons for this attitude. On the one hand, the determination of the permanent establishment's profits is surrounded by uncertainties and contradictions - the reason for the aforementioned extensive discussions - and, on the other hand, the permanent establishment is considered an unrealistic alternative for a subsidiary, particularly for commercial reasons such as the desired local image.

It seems to me that these objections to the permanent establishment are so far-reaching that, particularly in major transactions, the facilities of the Merger Directive will not play an important role if and insofar they result definitely in permanent establishments. This is a rather unappealing prospect, since the Directive is to play a crucial role in the creation and reorganization of Europe's enterprises.

The problem would be resolved if the permanent establishment resulting from a qualifying transaction (the 'merger' or the 'division' described in Articles 2(a) and 2(b) of the Directive) could subsequently be transferred tax-free into a local subsidiary. I believe that the third type of facilitated operations as described in Article 2(c) - 'the transfer of assets' - offers an opportunity for this purpose. Such an operation implies that a company 'transfers without being dissolved all or one or more branches of its activity to another company' in exchange for shares. A regularly stated example in the scarce literature on this type of operation is the situation in which a company in a Member State transfers its business to an unaffiliated company in another Member State in exchange for shares in the latter company. The business of the transferring company then remains as a permanent establishment in the original Member State.

The transfer of a permanent establishment into a local subsidiary falls within the scope of the 'transfer of assets' referred to in Article 2(c) of the Directive. Anyone who is somewhat familiar with the discussions in the work group that drew up the draft text of the Directive knows that it was considered self-evident that the transfer of the permanent establishment could be achieved tax-free. This would also conform with the rationale of the Directive in general and with that of the transfer of assets in particular. Unfortunately, this objective has been poorly reflected in the text of the Directive.

Because, what is the actual situation? Article 4, paragraph 1 of the Directive provides that, in cases of 'mergers' and 'divisions', the capital gains are tax-exempt only if the relevant assets and liabilities will be effectively connected with a permanent establishment of the transferring company in the Member State in which the transferring company is resident. The relevant part of the article reads as follows:

\footnotetext{
1 See Helmut Becker, 'The Renaissance of the Permanent Establishment' in: Intertax 1990/4, and, more detailed, 'Die steuerlichen Sekundärwirkungen in Gemeinsamen Markt', Zentrum für Europäisches Wirtschaftsrecht, Bonn 1990.

${ }_{2}$ Council Directive of the common system of taxation to mergers, divisions, transfers of assets and exchanges of shares concerning companies of different Member States (90/434/EEC).
} 
'A merger or division shall not give rise to any taxation of capital gains calculated by reference to the difference between the real values of the assets and liabilities transferred and their values for tax purposes. The following expressions shall have the meanings assigned to them:

- ...

- transferred assets and liabilities: those assets and liabilities of the transferring company which, in consequence of the merger or division, are effectively connected with a permanent establishment of the receiving company in the Member States of the transferring company and play a part in generating the profits or losses taken into account for tax purposes.'

The Directive contains no autonomous rules for the 'transfer of assets'. Title III, 'Rules applicable to transfers of assets', contains only one provision (Article 9), which reads:

'The provisions of Articles 4, 5 and 6 shall apply to transfers of assets.'

Literally, it could be argued that the 'transfer of assets' to a local subsidiary does not meet the requirement of Article 4, which states that the transferred assets and liabilities are to belong to a permanent establishment. ${ }^{3}$ As a consequence, the Member States would be free to tax the capital gains from the relevant assets. I do not believe such a strictly formal line of reasoning is convincing.

In my opinion, the reference made in Article 9 does not intend to apply all provisions set forth in Articles 4, 5 and 6 to the 'transfer of assets'; it merely strives to declare applicable those provisions that are relevant for the form of transfer chosen for the particular instance. The German text of the Directive reflects the relative value of the reference much more clearly than the Dutch or English version, in that the word 'entsprechend' has been added, thus indicating that the provisions set forth in Article 4 (among others) are only pertinent to the 'transfer of assets' where appropriate. It seems to me inappropriate to refuse facilities for the transfer of a permanent establishment into a local subsidiary only because the transfered assets and liabilities will obviously not form part of a permanent establishment in the Member State of the transferring company. Indeed, the requirement of a permanent establishment provides security for a Member State to impose future taxation if the assets and liabilities leave a local company and are transferred tax-free to a company established in another Member State. The transfer of assets to a local subsidiary offers even more security for the Member State regarding its tax claim on the capital gains. In those cases, it seems quite inappropriate to declare applicable a provision set forth in Article 4 that is relevant to all forms of 'mergers' and 'divisions' described in the Merger Directive, but not at all to this specific instance of 'transfer of assets'.

However, it remains rather incongruous that a legal concept of such practical import for the Directive is treated so carelessly.

This is even more serious, since it has appeared that various Member States seem to be somewhat overcome by the Merger Directive, the impact of which was apparently underestimated. A strictly formal interpretation would then provide an attractive opportunity for trying to limit the scope of the Directive. The first signs have already surfaced that the issue may give rise to considerable conflicts between the mutual Member States and the Member States and the Commission.

The emerging row brings back to mind a remark by another editor of Intertax, David Oliver, who recently noted in a typically British understatement: 'One wonders, ...., whether in relation to the July 1990 directives and the November 1990 proposal, sufficient expertise is going into the initial drafting of these directives,.5

\footnotetext{
3 See for instance Barry Larking: 'The Merger Directive: will it work?', European Taxation, December 1990, p. 362 et seq.

${ }^{4}$ It has also been defended by some that the text of Article 10 (the only provision in 'Title IV, Special Case of the Transfer of a Permanent Establishment') is literally applicable to the incorporation of a permanent establishment. This argument is notwithstanding the fact that it was probably written with a different objective in mind, that is, the case where the permanent establishment is situated in a third Member State. See Brigitte Knobbe-Keuk, 'Wegzug und Einbringung von Uternehmen zwischen Niederlassungsfreiheit, Fusionsrichtlinie und nationalem Steuerrecht', Der Betrieb, 8 February, 1991, p. 303.

5 J.D.B. Oliver, 'The drafting of European Community Directives' in Intertax 1991/5, page 248.
} 